\section{Hyaluronidase improves regional ophthalmic anaesthesia with etidocaine}

J. Sarvela MD, P. Nikki MD PhD.
The effect of adding hyaluronidase to regional ophthalmic anaesthesia with etidocaine $1.5 \%$ was examined. Two studies were performed in a double-blind fashion. In Study \#1, 70 patients were given peribulbar anaesthesia with etidocaine either with or without hyaluronidase $\left(7.5 \mathrm{IU} \cdot \mathrm{ml}^{-1}\right)$ using a standard intraorbital injection and separate lid injections. The block was supplemented as needed. Lower intraorbital volumes $(6.4 \pm 2.2$ $\mathrm{ml}$ vs $8.2 \pm 2.3 \mathrm{ml}, P<0.01)$ and improved scores for globe akinesia $(P<0.01)$, lid akinesia $(P<0.01)$ and analgesia $(P<$ $0.05)$ were recorded in the hyaluronidase group than in the plain etidocaine group. In Study $\$ 2,80$ patients were randomized to receive etidocaine and hyaluronidase either at a concentration of $7.5 \mathrm{IU} \cdot \mathrm{m} t^{-1}$ or $15 \mathrm{IU} \cdot \mathrm{m} t^{-1}$ using a two-injection-site technique. No differences were noted in the volumes of local anaesthetics required or in the success rates between the two groups. It was concluded that the addition of hyaluronidase to etidocaine decreases the volume needed and improves the quality of block compared with plain etidocaine. Doubling the dose of hyaluronidase does not improve the effectiviness of block.

Cette étude évalue les effets de l'addition d'hyaluronidase à l'anesthêsie régionale opthtalmique à l'étidocaïne 1.5\%. Deux études à double insu sont réalisées. Dans l'étude I, soixante-dix patients reçoivent une anesthésie péribulbaire d'étidocaïne avec ou sans hyaluronidase $7,5 \mathrm{UI} \cdot \mathrm{ml}^{-1}$ par injections intraorbitales standard et palpébrale séparées. Le block est supplémenté au besoin. Les volumes intraorbitaux injectés sont moindres $(6,4 \pm 2,2 \mathrm{ml}$ comparativement à $8,2 \pm 2,3, P<0,01)$;

\section{Key words}

ANAESTHETIC TECHNIQUES: regional, peribulbar; ANAESTHETICS, LOCAL: etidocaine; hyaluronidase; SURGERY: ophthalmic.

From the Eye Hospital, Department of Anaesthesia, Helsinki University Central Hospital, Helsinki, Finland.

Address correspondence to: Dr. J. Sarvela, Department of Anaesthesia, Eye Hospital, Helsinki University Central Hospital, Haartmanink. 4 C, 00290 Helsinki, Finland.

Accepted for publication Ist July, 1992. on note une amélioration pour l'akinésie globulaire $(P<0,01)$, l'akinésie palpébrale $(P<0,01)$ et l'analgésie $(P<0,01)$ dans le groupe hyaluronidase. Dans l'étude II, quatre-vingts patients sont distribués de façon aléatoire pour recevoir l'étidocaïne avec hyaluronidase à des concentrations de $7,5 \mathrm{UI} \cdot \mathrm{ml}^{-1}$ ou 15 $U I \cdot m l^{l}$ par une technique à deux sites d'injections. On n'a pas constaté de différence pour les volumes d'anesthésique requis ou le taux de succès entre les deux groupes. L'hyaluronidase permet de diminuer le volume et améliore la qualité du block comparativement à l'étidocaïne pure. Doubler la dose d'hyaluronidase n'améliore en rien l'efficacité du block.

The use of hyaluronidase has been shown to reduce the induction time of retrobulbar anaesthesia and also to improve the quality of the block. ${ }^{1}$ The addition of hyaluronidase to bupivacaine or a mixture of bupivacaine and lidocaine ${ }^{1-3}$ has been shown to enhance akinesia during retrobulbar anaesthesia.

Etidocaine, an amide-type local anaesthetic with rapid onset and long duration, has been used in retrobulbar blocks both without ${ }^{4}$ and with hyaluronidase. ${ }^{5.6}$ To our knowledge, no reports exist comparing etidocaine with the combination of etidocaine and hyaluronidase. Thus, a double-blind, prospective, randomized study was done to determine the comparative efficacy of a etidocaine $1.5 \%$ hyaluronidase solution and plain etidocaine $1.5 \%$ during cataract surgery for periocular anaesthesia (Study \#1). The second part of the study examined the use of two different doses of hyaluronidase $\left(7.5 \mathrm{IU} \cdot \mathrm{ml}^{-1}\right.$ and $\left.15 \mathrm{IU} \cdot \mathrm{ml}^{-1}\right)$ (Study \#2).

\section{Methods}

Following Ethics approval and informed consent, patients were randomly assigned to two groups. The patients belonged to ASA physical status I-III. Uncooperative patients and patients who had muscular or peripheral nerve diseases were excluded from the study.

Patients received lorazepam 1-2 $\mathrm{mg}$ po as premedica tion and fentanyl $25-50 \mu \mathrm{g}$ iv prior to the peribulbar block. The solutions used were prepared immediately before the injection by a theatre nurse. They were administered in a 
TABLE I Scoring system - Study \#1

Akinesia of extraocular muscles including levator muscle
$0=0-1 \mathrm{~mm}$ movement in any main direction or $0-4 \mathrm{~mm}$ movement
$\quad$ in levator muscle
$\begin{aligned}= & 2 \mathrm{~mm} \text { movement in any main direction or more than } 4 \mathrm{~mm} \text { move- } \\ & \text { ment in levator muscle }\end{aligned}$
$2=>2 \mathrm{~mm}$ movement in any main direction (general anesthesia)
Akinesia of orbicular muscle
$0=$ Complete akinesia
$1=$ Partial movement
$2=$ Pronounced movement
Analgesia
$0=$ No pain
$1=$ Partial pain
$2=$ Marked pain

predetermined, randomized fashion. The investigator was unaware of the mixtures chosen.

\section{Study \#1}

Seventy consecutive patients, admitted for cataract surgery, were examined and enrolled in the study. Half of the patients received a peribulbar injection of a solution containing etidocaine $1.5 \%$ (Duranest, Astra, Sweden) and hyaluronidase $7.5 \mathrm{IU} \cdot \mathrm{ml}^{-1}$ (Hyason, Organon, Holland), and half were given etidocaine $1.5 \%$ without hyaluronidase.

The first injection $(5 \mathrm{ml})$ was administered using a sharp $25 \mathrm{~g}$ needle, $25 \mathrm{~mm}$ in length (Terumo, Belgium) percutaneously at the point between the medial $2 / 3$ and the lateral $1 / 3$ of the inferior orbital rim along the floor of the orbit. Gentle digital massage was applied for one minute after the injection. The second injection $(3.5 \mathrm{ml})$ was infiltrated into each eyelid. An intraocular pressure reducer (Autopressor, Storz, Heidelberg, Germany) was applied for $15 \mathrm{~min}$ at a pressure of $25 \mathrm{mmHg}$.

Patients were asked to move their eyes using maximum effort in each of four directions (superior, inferior, medial and lateral), and then to open their eyelids and to squeeze them together. The opening capacity of the eye (indicating levator muscle force) and the movements of the extraocular muscles in all four main directions (measuring rectus muscle movements) were measured at five-minute intervals for $30 \mathrm{~min}$ unless akinesia had been achieved earlier. The force used to squeeze the eyes together was graded from $0-2$ (corresponding to the orbicular ocular muscle). The results were scored as shown in Table I. A supplemental injection (2-3 ml of previous solution) was administered in the same injection site as the original at 15 min as needed. In some cases a third injection was needed 25 min after the first injection. Analgesia was assessed by questioning the patient about pain perioperatively.
TABLE II Scoring system - Study \#2

Akinesia of extraocular muscles including levator muscle

$0=$ Complete akinesia $(0 \mathrm{~mm}$ movement in any main direction or in levator muscle)

$1=1 \mathrm{~mm}$ movement in any main direction or in levator muscle

$2=2 \mathrm{~mm}$ movement in any main direction or in levator muscle

Akinesia of orbicular muscle

$0=$ Complete akinesia

1 = Partial movement

2 = Pronounced movement

Analgesia

$0=$ No pain

1 = Partial pain

2 = Marked pain

\section{Study \#2}

Eighty consecutive patients, scheduled for cataract surgery under regional anaesthesia, were studied. They were randomly assigned to one of two groups. The first group received etidocaine $1.5 \%$ and hyaluronidase at a final concentration of $7.5 \mathrm{IU} \cdot \mathrm{ml}^{-1}$ and the second group with etidocaine $1.5 \%$ and hyaluronidase $15 \mathrm{IU} \cdot \mathrm{ml}^{-1}$. A 2-ml injection $(10 \mathrm{ml}$ balanced salt solution and $3.3 \mathrm{ml}$ lidocaine $2 \%$ and $0.3 \mathrm{ml}$ bicarbonate) was given subconjunctivally to reduce the pain of the first periocular injection. The same needles were used as in Study \#1. Initially two peribulbar injections were given, the first $(3-4 \mathrm{ml})$ from the same point as in Study \#1 but through the conjunctiva, with $0.5 \mathrm{ml}$ being injected during withdrawal of the needle in order to achieve lower lid akinesia. The second injection (2-4 ml) was given from the medial corner of the caruncle transconjunctivally. Digital massage and the autopressor were applied as in Study \#1.

At 5,15 and $30 \mathrm{~min}$ after the initial injections the extraocular eye movements and movement of the levator muscle and lid akinesia were assessed as in Study \#1. After each measurement, supplemental injections were given when needed, either peribulbarly $(2-3 \mathrm{ml})$ or by infiltration (1-5 ml) to the lids. The results were converted into scores as shown in Table II.

Results are expressed as mean \pm SD. Differences between the groups were compared by means of the MannWhitney $U$ test with two-sided significance levels. A $P$ value $<0.05$ was considered significant.

\section{Results}

\section{Study \#1}

The patients were comparable in the hyaluronidase group and plain etidocaine groups with respect to age (74.4 \pm 10.1 yr vs $73.0 \pm 9.3$, NS), BMI (26.9 \pm 5.1. vs $25.9 \pm$ $4.5, \mathrm{NS})$ and sex (28/7 vs $29 / 6$, female/male ratio, NS). 


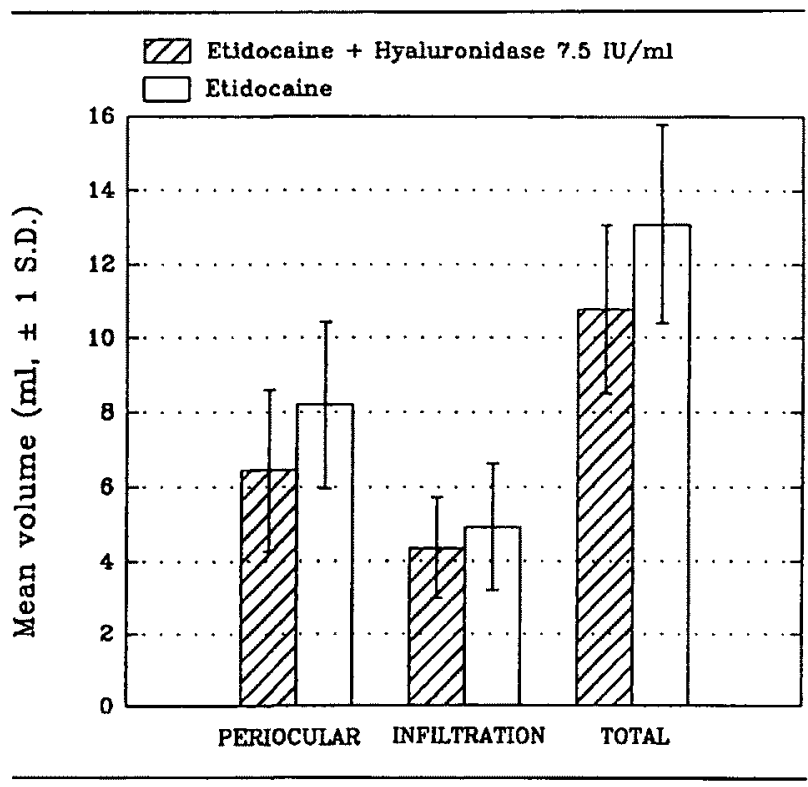

FIGURE 1 Local anaesthetic volumes injected into the periocular space and infiltrated into the lids, and their sum (total) using $1.5 \%$ etidocaine with $7.5 \mathrm{IU} \cdot \mathrm{ml}^{-1}$ hyaluronidase vs plain $1.5 \%$ etidocaine.

TABLE III Study\#1

\begin{tabular}{llcl}
\hline & Score 0 & Score 1 & Score 2 \\
\hline $\begin{array}{l}\text { Globe akinesia } \dagger \\
\text { Etidocaine }+ \text { hyaluronidase }\end{array}$ & & & \\
$\quad 7.5 \mathrm{IU} \cdot \mathrm{ml}^{-1}$ & 27 & 7 & 1 \\
Etidocaine & 15 & 15 & 5 \\
& & & \\
Lid akinesia $\dagger$ & & & \\
Etidocaine + hyaluronidase & 29 & 6 & 0 \\
$\quad \begin{array}{l}7.5 \mathrm{IU} \cdot \mathrm{ml}^{-1} \\
\text { Etidocaine }\end{array}$ & 15 & 20 & 0 \\
$\begin{array}{l}\text { Analgesia* } \\
\text { Etidocaine }+ \text { hyaluronidase }\end{array}$ & & & \\
$7.5 \mathrm{IU} \cdot \mathrm{ml}^{-1}$ & 21 & & \\
Etidocaine & 8 & 11 & 2 \\
\hline
\end{tabular}

${ }^{*} P<0.05 . \dagger P<0.01$.

$(0=$ complete akinesia/analgesia, $1=$ partial movement/pain,

$2=$ pronounced movement/marked pain.)

Lower periocular and total volumes were needed in the group receiving hyaluronidase $(6.4 \pm 2.2$ vs $8.2 \pm 2.3$, $P<0.01$ and $10.8 \pm 2.3$ vs $13.1 \pm 2.7, P<0.01$, respectively) (Figure 1). There were no differences between the groups in the infiltration volumes to the lids (extraorbital volume).

The success rates of the blocks at $15 \mathrm{~min}$ are shown in Table III. For akinesia of the globe $(P<0.01)$, akinesia of the lids $(P<0.01)$ and analgesia $(P<0.05)$ better results were obtained with the addition of hyaluronidase. The incidence of failure was $6 \%$ in the etidocaine with hyal-

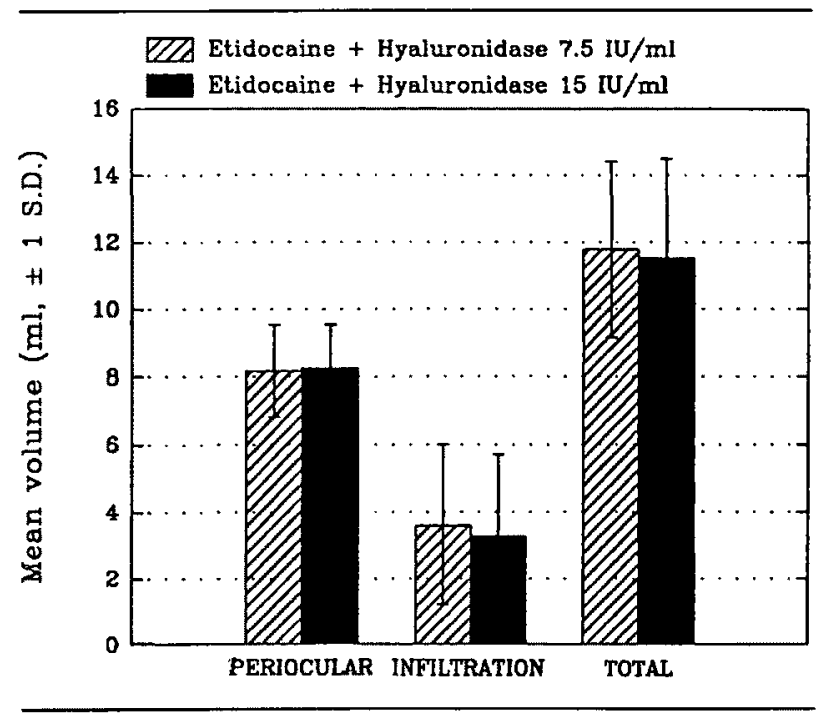

FIGURE 2 Local anaesthetic volumes injected into the periocular space and infiltrated into the lids, and their sum (total) using $1.5 \%$ etidocaine with $7.5 \mathrm{IU} \cdot \mathrm{ml}^{-1}$ or $15 \mathrm{IU} \cdot \mathrm{ml}^{-1}$ hyaluronidase.

uronidase and $15 \%$ in etidocaine group. Due to failure of regional anaesthesia, one patient in the former group and five patients in the latter group were given general anaesthesia. The time which elapsed from the beginning of the regional anaesthesia to the beginning of the operation was $59 \pm 17 \mathrm{~min}$ and to the end of operation $104 \mathrm{~min} \pm 30$ min.

\section{Study \#2}

The patients were matched for age $(71.2 \pm 13.8 \mathrm{yr}$ in hyaluronidase $7.5 \mathrm{IU} \cdot \mathrm{ml}^{-1}$ group vs $71.5 \pm 12.2$ in hyaluronidase $15 \mathrm{IU} \cdot \mathrm{ml}^{-1}$ group, NS), BMI $(26.4 \pm 4.4 \mathrm{vs}$ $24.9 \pm 3.5, \mathrm{NS}$, respectively) and for sex (24:16 vs $18: 22$, female/male ratio, NS, respectively).

The mean volumes of solutions required are shown in Figure 2. There were no significant differences in volumes or success rates when analyzed in subgroups as in Study \#1 (Table IV).

One patient in each group experienced marked pain during the operation, and these two cases were considered as failures. No general anaesthesia was needed. In the group receiving hyaluronidase $15 \mathrm{IU} \cdot \mathrm{ml}^{-1}$ one patient had a subconjunctival haematoma and the operation was cancelled. The time from administration of the block to the beginning of the operation was $44 \pm 18 \mathrm{~min}$ and to the end of the operation $85 \pm 25 \mathrm{~min}$.

\section{Discussion}

In the present study the advantages of the addition of hyaluronidase to etidocaine during cataract surgery resulted in better globe akinesia, lid akinesia and analgesia. These are all essential for a successful outcome in cataract 
TABLE IV Study \#2

\begin{tabular}{llll}
\hline & Score 0 & Score I & Score 2 \\
\hline $\begin{array}{l}\text { Globe akinesia } \\
\text { Etidocaine }+ \text { hyaluronidase } \\
7.5 \mathrm{IU} \cdot \mathrm{ml}^{-1}\end{array}$ & 39 & 1 & 0 \\
$\begin{array}{l}\text { Etidocaine }+ \text { hyaluronidase } \\
15 \mathrm{IU} \cdot \mathrm{ml}^{-1}\end{array}$ & 39 & 0 & 1 \\
$\begin{array}{l}\text { Lid akinesia } \\
\text { Etidocaine }+ \text { hyaluronidase } \\
7.5 \mathrm{IU} \cdot \mathrm{ml}^{-1}\end{array}$ & 33 & 7 & \\
$\begin{array}{l}\text { Etidocaine }+ \text { hyaluronidase } \\
15 \mathrm{IU} \cdot \mathrm{ml}^{-1}\end{array}$ & 30 & 9 & 0 \\
$\begin{array}{l}\text { Analgesia } \\
\text { Etidocaine }+ \text { hyaluronidase } \\
7.5 \mathrm{IU} \cdot \mathrm{ml}^{-1}\end{array}$ & 30 & 8 & 1 \\
$\begin{array}{l}\text { Etidocaine }+ \text { hyaluronidase } \\
15 \mathrm{IU} \cdot \mathrm{ml}^{-1}\end{array}$ & 33 & 5 & 1 \\
\hline
\end{tabular}

$(0=$ complete akinesia/analgesia, 1 = partial movement/pain,

$2=$ pronounced movement/marked pain.)

surgery performed under regional anaesthesia. Also, in this trial, the intraorbital volumes were smaller in the hyaluronidase group. However, increasing the dose of hyaluronidase did not improve the results.

In regional anaesthesia of the eye addition of hyaluronidase to bupivacaine $(0.75 \%)$, to lidocaine $(2 \%)$ or to a mixture of bupivacaine $(0.5 \%)$ and lidocaine $(2 \%)$ have been shown to produce more profound retrobulbar blocks than without it. ${ }^{2,7.1,3}$ Adding hyaluronidase to mepivacaine, however, has shortened the duration of retrobulbar block compared with plain mepivacaine. ${ }^{8}$ Mindel found no improvement in akinesia when hyaluronidase was added to mepivacaine $(2 \%)$ in retrobulbar anaesthesia. ${ }^{9}$ In epidural ${ }^{10}$ and some regional nerve blocks" hyaluronidase has not proved to be beneficial.

There are a number of reasons why hyaluronidase improves the quality of block in the regional anaesthesia of the eye, while having no effect in other regional blocks. The bony orbit forms a rather limited space, where the action of hyaluronidase could be more localised thus hindering further dispersal of the anaesthetic. ${ }^{1}$ The retrobulbar space is filled with orbital fat, arranged in globules separated by interglobular septa of variable density. ${ }^{12}$ Hyaluronidase may promote the diffusion of the local anaesthetic more easily in such a place than in other parts of the body with thicker membranes. In addition, the artificially increased pressure induced by a Honan type autopressor device may enhance the effect of the enzyme. ${ }^{13}$

Although the results of the two parts of our study are not directly comparable, better scores for globe akinesia and analgesia were noted in the second part of the study. This may be due to two reasons: firstly, in the latter study a two-injection-site technique was used, while in the former initially only one larger injection was administered periorbitally. The local anaesthetic may disperse better from the medial injection site to the orbital structures that lie far from the inferolateral injection site (the superior oblique muscle and the medial rectus muscle) and better success rates are achieved initially. The second explanation may be the increased level of skill of the anaesthetist during the latter part of the study.

Another possibility of improving the efficacy of etidocaine is adding epinephrine to it. ${ }^{14}$ This has been demonstrated in epidural anaesthesia although a lower concentration $(0.5 \%)$ of etidocaine was utilized in that trial. The use of epinephrine in regional ophthalmic anaesthesia is debatable, however, because marked reduction in ophthalmic artery pulse pressure has been observed after retrobular anaesthesia with lidocaine and epinephrine. ${ }^{15}$

During the use of traditional retrobulbar anaesthesia several complications have been reported. ${ }^{16}$ This explains why in many eye clinics shorter needles are now used. In the technique known as the periocular technique the doses of local anaesthetics are usually greater than with retrobulbar anaesthesia. In order to obtain optimal conditions for ophthalmic surgery and to avoid systemic or central nervous system complications, it is important to aim at the lowest effective dose of local anaesthetic. The value of hyaluronidase is obvious, since lower intraorbital volumes of local anaesthetic are needed.

It can be concluded that better blocks with smaller volumes are obtained if hyaluronidase is added to etidocaine during cataract surgery under regional anaesthesia. This study showed that $7.5 \mathrm{IU} \cdot \mathrm{ml}^{-1}$ hyaluronidase is sufficient and that doubling the dose does not have any beneficial effects.

\section{Acknowledgements}

The study was supported by the Paulo Foundation, Helsinki, Finland. Preliminary results from the study were presented at the XXX Nordic Congress of Ophthalmology in Helsinki, Finland, August 25-28, 1991 and at the IX European Intraocular Implantlens Congress in Valencia, Spain, September 10-14, 1991.

\section{References}

1 Nicoll JMV, Treuren B, Acharya PA, Ahlen K, James $M$. Retrobulbar anaesthesia: the role of hyaluronidase. Anesth Analg 1986; 65: 1324-8.

2 Lange W, Denffer HV, Honis $M$. Comparison of bupivacaine $(0.75 \%)$ with a mixture of bupivacaine $(0.75 \%)$ and mepivacaine $(2 \%)$ in retrobulbar anesthesia: effects of hyaluronidase. Fortschr Ophthalmol 1989; 86: 312-5. 
3 Abelson $M B$, Mandel $E$. The effect of hyaluronidase on akinesia during cataract surgery. Ophthalmic Surg 1989; 20: 325-7.

4 Thornburn W, Thorn-Alquist A-M, Edström H. Etidocaine in retrobulbar anaesthesia. Acta Ophthalmol 1976; 54: $591-600$.

5 Smith PH, Kim JW. Etidocaine used for retrobulbar block: a comparison with lidocaine. Ophthalmic Surg 1980; 11: 4, 268-73.

6 Smith $P H$, Smith ER. A comparison of etidocaine and lidocaine for retrobulbar anesthesia. Ophthalmic Surg 1983; 14: 7, 569-74.

7 Thomson I. Addition of hyaluronidase to lignocaine with adrenaline for retrobulbar anaesthesia in the surgery of senile cataract. Br J Ophthalmol 1988; 72: 700-2.

8 Szmyd SM, Nelson LB, Calhoun JH, Harley RD. Retrobulbar anesthesia in strabismus surgery. Arch Ophthalmol 1984; 102: 1325-7.

9 Mindel JS. Value of hyaluronidase in ocular surgical akinesia. Am J Ophthalmol 1978; 85: 643-6.

10 Scott DB. Hyaluronidase in epidural analgesia. $\mathrm{Br} \mathrm{J}$ Anesth 1956; 28: 187-92.

11 Eckenhoff $J E$, Kirby $C K$. The use of hyaluronidase in regional nerve blocks. Anesthesiology 1951; 12: 27-32.

12 Koornneef $L$. Spatial Aspects of Orbital Musculo-fibrous Tissue in Man. Amsterdam: Swets \& Zeitlinger, 1977.

13 Lebensohn JE. Hyaluronidase in ocular surgery and therapy. Am J Ophthalmol 1950; 33: 865-70.

14 Finucane BT, McCraney JM, Bush DF. Double-blind comparison of lidocaine and etidocaine during continuous epidural anesthesia for vaginal delivery. South Med J $1978 ; 71: 6,667-70$.

15 Hoerven 1 . Ophthalmic artery pressure during retrobulbar anesthesia. Acta Ophthalmol 1978; 56: 574-86.

16 Nicoll JMV, Acharya PA, Ahlen K, Baguneid S, Edge KR. Central nervous system complications after 6000 retrobulbar blocks. Anesth Analg 1987; 66: 1298-302. 